\title{
The Regular School Strategies in the Implementation of Inclusive Education for Strengthening the Character of Tolerance
}

\author{
Arum Pertiwi ${ }^{1, *}$ Suharno ${ }^{2}$ \\ ${ }^{1}$ Department of Pancasila and Civic Education, Faculty of Social Science, Yogyakarta State University, Yogyakarta \\ Indonesia \\ ${ }^{2}$ Department of Pancasila and Civic Education, Faculty of Social Science, Yogyakarta State University, Yogyakarta \\ Indonesia \\ *Corresponding author. Email: arum63pasca.2019@student.uny.ac.id
}

\begin{abstract}
The implementation of inclusive education in regular schools has not fully implemented the system stipulated in the Regulation of the Minister of National Education of the Republic of Indonesia Number 70 of 2009 concerning inclusive education for disabled and gifted students, which special so that the character of tolerance needs to be strengthened in regular school. The research method employed was descriptive with a qualitative approach-the three sources in this study. Data collection techniques were observation and interviews. The data analysis used were data reduction, data presentation, and conclusion drawing. This paper discussed the strategy of regular schools in implementing inclusive education to strengthen students' tolerance. The results of this study were that the strategies applied were 1) internalizing the value of tolerance in the learning process, 2) providing a role model from a teacher, and 3 ) the family that monitored the process of strengthening tolerance character.
\end{abstract}

Keywords: Strategy, Inclusive Education, and Character of Tolerance

\section{INTRODUCTION}

A school is a place for students to implement a formal education. An educational institution such as schools is a place to transfer knowledge and a place used to build student's character education and an area of bonding the interaction among school communities. The formal education process is performed based on binding rules (Iqbal \& Darmawan, 2021). The purpose of regulations is to provide discipline for school members to comply with the rules (Yusuf, 2020). The learning process in schools internalizes multicultural and inclusive values so that students are accustomed to having a strong character (Ediyanto \& Prabowo, 2017).

Regular schools in North Sumatra have not implemented inclusive values in regular school (Martin, 2021). It showed that the Regulation of the Minister of the Republic of Indonesia Number 70 of 2009 concerning inclusive education for students who have the potential for intelligence and/or special talents had not been implemented thoroughly in every province (Diana \& Munawir,2020). This problem needs to be carefully evaluated from the center to the province to implement inclusive education as a whole (Ekawati, 2010).

The preschool teachers encounter difficulties in the process of inclusive education implementation, for example, getting difficulties to deal with children with special needs and lacking understanding of knowledge and skills about inclusive classes (Richards \& Amstrong, 2015). There is a need for teacher training in the implementation of inclusive education (Siti, 2020). It can be claimed that its implementation is not only to the applied regulations which have to be executed, but it needs to be supported by each individual to be involved (Skiba, 2000). Hence, the implementation of inclusive education must be supported by the bound regulation and cooperation from the central government into the province, school members, and the community (Kistoro, 2021).

Teachers might not understand to offer the best solutions to inclusive problems. Special training for inclusive education services and the problem of tolerance of school members against children with special needs become a significant concern in 
implementing inclusive education (Tyas, 2020). Based on the issue, this scholarly paper can be used to identify a solution to strengthening tolerance through regular school strategies in implementing inclusive education (Florian, 2010). The study provided an understanding of schools' importance in offering a specific strategy for applying inclusive education so that students have a strengthening character of tolerance (Alhadiq \& Wahyudin, 2020).

This current study discussed the strategy of regular schools in applying inclusive education to strengthen the character of tolerance (Haigh, 2002). The purpose of writing is to provide several ways for regular schools which can strengthen students' character of tolerance through inclusive education. This paper's novelty is that regular schools can implement inclusive education holistically and provide strengthening tolerance for students.

\section{METHOD}

The research used a qualitative approach with a descriptive type. The research is located in the Senior High School of 14 of Bandar Lampung (SMA 14 Bandar Lampung). The three main informants engaged in this study were student representatives, the viceprincipal of curriculum, and Pancasila and civic education teachers. The informants were chosen by using the purposive technique. The selected informants were based on understanding and involvement in inclusive education in regular schools, while the data collection techniques used were observation and interviews. The observation was conducted to obtain the desired initial data, whereas Interviews were carried out to get detailed data about regular school strategies in implementing inclusive education. The data analysis technique used was data reduction, data presentation, and conclusion drawing. The validities of the data used in this study were triangulation of sources and triangulation of techniques.

\section{RESULT AND DISCUSSION}

\subsection{Result}

The school strategy is a method used by the school to strengthen students' character and internalize education values. School strategies need to be given to students to strengthen the character of tolerance through inclusive education. The strategy given by the school must involve several education centers in inclusive education. The school environment and the family environment are two educational centers highly influential in strengthening the online learning process's tolerant character. Schools must be able to provide inclusive education to students so that students have to strengthen the tolerance character.

\subsection{Discussion}

\subsubsection{Inclusive Education}

According to Richards and Armstrong, an inclusive school comprised the following criteria. First, schools could be accessed by everyone physically, culturally, and educationally. Second, school members could convey their aspirations. Third, schools involved assessments through practical values. Fourth, schools could develop students' participation. Fifth, schools could create a curriculum with learning practices according to the needs of students. Sixth, students could provide good grades for schools. Seventh, schools could provide an understanding of equal opportunities for every school member. Eighth, the school offered an introduction to the community and developed the community environment. Ninth, school members could practice democratic values. Tenth, school members could recognize and respect differences.

The learning strategy for inclusive education must consist of several components: discussion, learning objectives, learning steps, learning methods, learning media, learning resources, and learning time. First, the topic of discussion must be by the theme to be taught to students and according to students' needs. Second, learning objectives are the aims and objectives of the learning process daily. Third, learning steps must be passed by students so that learning objectives are achieved properly. Fourth, the learning method is a method used by an educator so that the learning process can take place as desired (Cepic, 2015). Fifth, learning media is the media used by an educator in the learning process. Sixth, learning resources are teaching materials used by students in the learning process to internalize values and understand the concepts in certain materials. Seventh, learning time is one of the important strategies in the process of inclusive education. Students understand the theory and maximize the learning time that applies to practice the value of tolerance (Grima, 2011).

The process of strengthening the character of autistic students through three models to implement character education. They are explanation, practice, and intensive 
mentoring. It aims to train autistic children in terms of fostering children's concentration and focus. The training model is used to train autistic children with soft skills to strengthen the understanding of material and reasoning ability materials. In contrast, the intensive mentoring model for soft skills training for autistic children is related to the ability of interpersonal relationships and trust (Berkowitz, 2005). A teacher should have pedagogic, personal, and problem skills for character education for autistic children.

\subsubsection{The regular school strategy in implementing inclusive education is to strengthen the character of tolerance}

The process of strengthening the character of tolerance during the online learning period can be done by determining the right strategy. Better character education strategies based on problems, This step can provide a space for dialogue between school members. School strategies are needed to strengthen the tolerance character of students. Strengthening character is not only a process of giving awareness, but also students must be able to have a tolerant character wherever they are. The purpose of habituating the character of tolerance is that students are accustomed to having a tolerant character wherever and whenever.

The senior high school of 14 of Bandar Lampung is the only regular school that implements inclusive education in Bandar Lampung. This is based on the regulation of the minister of national education of the Republic of Indonesia Number 70 of 2009 concerning Inclusive Education for Students with Disabilities and Potential Intelligence and/or Special Talents, regular schools can implement inclusive education at every level of education, but not all regular schools implement education. Inclusive because there are many problems in implementing inclusive education in regular schools. The implementation of inclusive education at senior high school of 14 in Bandar Lampung is related to strengthening the character of tolerance in senior high school of 14 in Bandar Lampung, especially students.

The steps taken by senior high school 14 of Bandar Lampung in strengthening the character of tolerance through inclusive education are as follows. First, teachers of senior high school of 14 in Bandar Lampung attended training on inclusive education. Teachers of senior high school of 14 in Bandar Lampung receive training and a basic understanding of inclusive education for students. Second, students take part in the school introduction program, including inclusive education and strengthening the character of tolerance. This aims to make students understand diversity tolerance with schoolmates and the acceptance of students with special needs. Third, senior high school of 14 in Bandar Lampung provides facilities to support inclusive education in schools. The facilities for senior high school of 14 in Bandar Lampung can support inclusive education, namely the provision of special roads for the disabled, special facilities in the learning process for the blind, and special toilets for the disabled.

The steps taken by senior high school 14 of Bandar Lampung to strengthen tolerance through inclusive education are as follows; first, teachers of senior high school 14 of Bandar Lampung attended training on inclusive education. The teachers received training and a basic understanding of inclusive education for students. Second, students took part in the school introduction program, including inclusive education and strengthening the character of tolerance. This aimed to make students understand diversity tolerance with schoolmates and the acceptance of students with special needs. Third, the senior high school 14 of Bandar Lampung provided facilities to support inclusive education in schools. The facilities could support inclusive education, namely providing special roads for the disabled, special facilities in the learning process for the blind, and special toilets for the disabled.

Teachers attended inclusive education training. It is intended that teachers understand the basic concepts in applying inclusive education in regular schools, and teachers can implement the concepts of inclusiveness in the learning process and everyday life. The process of inclusive education training is the embodiment of the character of tolerance. Teachers accustom themselves to interacting and communicating with everyone to be used as role models for students with this. The example of a teacher is the initial capital to strengthen the character of tolerance in students. Inclusive education training can be used as a habit for teachers to have a character of tolerance and be used as an example.

Students joined in the school introduction program, including inclusive education and strengthening the character of tolerance. During the school introduction process, the school provided an understanding of inclusive education, how to interact with each student, the vision, mission, and goals of senior high school of 14 in Bandar Lampung. This shows that the school prepares early for the formation of students with tolerance characters. The school introduction process is used as a first step to understand the importance of 
strengthening the character of tolerance in inclusive schools. The learning process carried out by students is an implementation of the inclusiveness values that have been given at the beginning of the introduction to the school. Students are accustomed to being tolerant and open-minded in every situation.

The provision of facilities provided by senior high school of 14 in Bandar Lampung to support inclusive education in schools can be used to implement inclusive education. The school invited the senior high school residents of 14 in Bandar Lampung to implement inclusive education in the school environment. The provision of facilities is the first step so that school members become accustomed to tolerating differences. Supporting facilities for inclusive education need to be maintained and developed by school residents so that they are maintained.

The perception of tolerance needs the same principle in understanding tolerance. There are four difficulties in strengthening character, namely the application of character education is not carried out in the family environment, the environment does not provide a model of behavior that can be imitated, lack of motivation, and children do not get guidance and assistance in the educational process. The regular school strategy is to strengthen the character of tolerance through inclusive education at senior high school of 14 in Bandar Lampung by internalizing the value of tolerance in the learning process, providing a role model from a teacher, and the family monitoring the progress of strengthening the character of tolerance.

Internalizing the values of tolerance contributed to students' awareness so that they have an awareness of being tolerant in inclusiveness, as for the values of tolerant awareness, namely the value of respecting each individual, the value of respecting the opinions of others, the value of prioritizing common interests, the value of deliberation, and the value of working with others. The values of tolerance are given by the senior high school of 14 in Bandar Lampung to strengthen students' tolerance character.

Resource person As the student representative at senior high school of 14 in Bandar Lampung, teachers act as role models. Even though the learning process is online, the teacher still provides examples to students through the online learning process. It shows that the teacher plays a very important role in strengthening the character of tolerance virtually. Modeling is the second strategy in strengthening the character of tolerance through inclusive education at senior high school of 14 in Bandar Lampung. The teacher is used as a role model in the embodiment of the character of tolerance.

Habitual tolerance character is the teacher's way of reinforcing the character of tolerance at senior high school of 14 in Bandar Lampung. Students are given an example from the teacher, and then students must implement tolerance values. As for tolerant habituations that students must do, namely, students must be accustomed to respecting each individual, students must be accustomed to respecting other people's opinions, students must be able to prioritize common interests, students must be able to deliberate, and students must be able to work with people other. Habitual tolerance in everyday life can strengthen the character of tolerance of students.

The family monitors the progress of strengthening the tolerance character given by the teacher. Family plays an important role in the process of strengthening the character of tolerance of a child. Family is the starting place for tolerance. The online learning process involves the family in strengthening character. Teachers and families work together in strengthening the character of tolerance. The teacher gives assignments that can reinforce the character of tolerance, and the family monitors the progress of strengthening students' tolerance character. The strategies that regular schools have provided are ways for schools to strengthen the character of tolerance through inclusive education.

\section{CONCLUSION}

The study explained the need for a school strategy to strengthen tolerance through inclusive education in regular schools. The senior high school 14 of Bandar Lampung chose a strategy for strengthening the character of tolerance through inclusive education in regular schools by internalizing the values of tolerance in the learning process, providing a role model from a teacher, and the school monitoring the progress of strengthening the character of tolerance of a child.

The paper only discussed the strategy of regular schools in applying inclusive education to strengthen the character of tolerance, so that a different study is needed from the writing of this article. The writer hopes that the next writer can describe the study of strengthening the character of tolerance through inclusive education from another point of view. 


\section{ACKNOWLEDGMENTS}

Thank you to the interviewees in the senior high school 14 of Bandar Lampung. They were student representatives, the vice-principal of curriculum affairs, and teacher of Pancasila and civic education,

\section{REFERENCES}

[1] Iqbal, M., Sukristyanto, A., \& Darmawan, A. (2021). Implementation of Inclusive Education for Children with Special Needs in Regular Schools in North Sumatera Province. Journal of Public Policy and Administration, 5(1), 1.

[2] Ediyanto, E., Atika, I. N., Kawai, N., \& Prabowo, E. (2017). Inclusive education in Indonesia from the perspective of Widyaiswara in Centre for Development and empowerment of teachers and education personnel of kindergartens and special Education. IJDS: INDONESIAN JOURNAL OF DISABILITY STUDIES, 4(2), 104-116.

[3] Yusuf, M. (2020). Preschool Teachers' Attitude Toward Inclusive Education in Central Java, Indonesia. In 3rd International Conference on Learning Innovation and Quality Education (ICLIQE 2019) (pp. 1361-1368).

[4] San Martin, C., Ramirez, C., Calvo, R., MuñozMartínez, Y., \& Sharma, U. (2021). Chilean Teachers' Attitudes towards Inclusive Education, Intention, and Self-Efficacy to Implement Inclusive Practices. Sustainability, 13(4), 2300.

[5] Diana, D., Sunardi, S., Gunarhadi, G., \& Munawir, Y. (2020). The development of I-Teach model to improve early childhood teachers professionalism. Cypriot Journal of Educational Sciences, 15(6), 1614-1628.

[6] Ekawati, N. P., Skor, P. A. M. T. P., Negeri, I. P. R. D. S., Jaya, R., Haryono, A., Rindiarti, A., ... \& Setiawati, A. Al-Qur'an dan Al Hadits Arikunto, Suharsimi (2010). Prosedur Penelitian Suatu Pendekatan Praktik. Jakarta: Rineka Cipta Asriadi B, Fajriansi A, Darwis (2014).“Faktor-faktor yang berhubungan dengan kejadian insomnia pada warga di Kelurahan Bontoa Kecamatan Mandai. Jurnal Psikologi Indonesia, 12, 2.

[7] Richards, G., \& Armstrong, F. (Eds.). (2015). Teaching and learning in diverse and inclusive classrooms: Key issues for new teachers. Routledge.

[8] Siti, L. (2020). Telaah Kemampuan Dasar Menulis Karya Ilmiah Mahasiswa Pendidikan Biologi Uin Raden Intan Lampung (Doctoral dissertation, UIN Raden Intan Lampung).

[9] Kistoro, C. A. (2021). Teachers' Experiences in Character Education for Autistic Children. International Journal of Evaluation and Research in Education, 10(1), 65-77.

[10] Skiba, R. J., \& Peterson, R. L. (2000). School discipline at a crossroads: From zero tolerance to early response. Exceptional children, 66(3), 335346.

[11] Alhadiq, M. F., \& Wahyudin, D. (2020, February). Teacher's Perception of Tolerance Among Elementary School Students. In International Conference on Educational Psychology and Pedagogy-" Diversity in Education"(ICEPP 2019) (pp. 86-90).

[12] Tyas, E. H., \& Naibaho, L. (2020). Building a Culture of Tolerance since Early Childhood. International Journal of ResearchGRANTHAALAYAH, 8(8), 244-249.

[13] Florian, L., \& Linklater, H. (2010). Preparing teachers for inclusive education: using inclusive pedagogy to enhance teaching and learning for all. Cambridge journal of education, 40(4), 369386.

[14] Haigh, M. J. (2002). Internationalisation of the curriculum: Designing inclusive education for a small world. Journal of Geography in Higher Education, 26(1), 49-66.

[15] Grima, F. C. R., Bain, A., \& McDonagh, S. H. (2011). Bridging the research-to-practice gap: A review of the literature focusing on inclusive education. Australasian Journal of Special Education, 35(2), 117-136.

[16] Cepic, R., Vorkapic, S. T., Loncaric, D., Andic, D., \& Mihic, S. S. (2015). Considering transversal competences, personality and reputation in the context of the teachers' professional development. International Education Studies, 8(2), 8-20.

[17] Berkowitz, M. W., \& Bier, M. C. (2005). What works in character education: A research-driven guide for educators. Washington, DC: Character Education Partnership. 